\title{
PUBLIC FINANCE DURING THE REIGN OF CATHERINE THE GREAT
}

\author{
Lyudmila V. GUDAKOVA ${ }^{\text {a, }}$, \\ Elena D. GREBENNIKOVA ${ }^{\text {b }}$
}

\author{
${ }^{a}$ Kuban State University (KubSU), \\ Krasnodar, Krasnodar Krai, Russian Federation \\ gudlud@yandex.ru \\ https://orcid.org/0000-0002-7078-7721 \\ ${ }^{\mathrm{b}}$ Kuban State University (KubSU), \\ Krasnodar, Krasnodar Krai, Russian Federation \\ grelena2019@mail.ru \\ https://orcid.org/0000-0002-0934-8594 \\ - Corresponding author
}

\section{Article history:}

Article No. 580/2021

Received 25 Oct 2021

Received in revised form 11 November 2021

Accepted 28 Nov 2021

Available online

27 December 2021

JEL: B1, B15, B31, N00, N10

Keywords:

Catherine the Great, currency, monetary circulation, financial reform, monetary policy

\section{Abstract}

Subject. We study the main directions and special aspects of the monetary system development during the reign of Catherine II. We discuss the monetary reform associated with the introduction of bank notes and the emergence of the banking system, as well as the creation of new financial systems.

Objectives. We focus on identifying the economic reasons that propelled Catherine the Great to use a new instrument of State regulation of the financial system, on showing how the creation of the banking system, still within the conditions of serfdom, acquired its own specifics.

Methods. We apply the logical, historical and diachronous approaches, economic research methods. We also use the principles of historical method, dialectics, the method of scientific abstraction and analysis, which determine the foundations of the financial reforms of Catherine the Great.

Results. We revealed the role of creating the banking system and non-banking institutions during the second half of the eighteenth century, classified their types and goals, determined the main characteristics of paper money. The monetary reform of Catherine the Great, which created favorable conditions for external borrowings, ensured the recovery of public finance in general.

Conclusions. The study concludes on important role of State regulation in the development of financial infrastructure, on the need to use the experience in the modern practice of private enterprise development and capital accumulation. The findings can be used in lectures and seminars for basic courses, like History of Finance and Economic History.

(c) Publishing house FINANCE and CREDIT, 2021

The editor-in-charge of this article was Andrey V. Bazhanov

Please cite this article as: Gudakova L.V., Grebennikova E.D. Public Finance During the Reign of Catherine the Great. Digest Finance, 2021, vol. 26, iss. 4, pp. 434-444. https://doi.org/10.24891/df.26.4.434 


\section{Introduction}

In the development of economic thought at different stages of Russian history, the mercantilist trend is actualized, which through the prism of its methodology, opens a new look at the financial policy of Catherine II. Representatives of this direction, Jean-Baptiste Colbert, Thomas Man and Antoine de Moncretien, consider economic growth as an increase in wealth in the country due to the regulation of foreign trade, while a positive trade balance is obtained.

The reign of Catherine II (1762-1796) not only occupies a special place in the history of Russian diplomacy, but also plays a system-forming role in the formation and development of economic methods and principles of regulation of all parts of the financial system.

At her accession to the throne, Catherine enjoyed universal favor. When they offered to give her the nickname "Mother of the Fatherland", she resolutely refused to accept this honor, noting at the same time: "It seems to me that it is too early to offer this project, because they will explain it to the world for vanity" [1]. Catherine played a major role in the governance of the state in the financial system of the Russian Empire, which acquired more modern economic institutions for the period of enlightened absolutism [2-5].

\section{Budget policy of Catherine II}

Catherine II focused not only on social and cultural reforms, but also on economically important issues of the country.

In general, the state of finances required drastic changes during the reign of Catherine II. The Empress introduced the principles of financial management, which were based on the introduction of new methods of statistical analysis in the field of budget, in the financial management system, and also laid the foundations of the banking system in Russia.

In the field of administration, Catherine II lent money to the Governing Senate, and also adopted a decree: to sell "the lands that are not experienced in dachas, but to the nobles... necessary lands", as well as to appoint judicial workers "to each a decent salary, finding money for that, again imposed from the people by fees, but in other decent ways" [6], these measures were taken to maintain and strengthen public finances. The treasury was still the main indicator of the well-being of the financial system, and therefore the most significant changes in the replenishment of the treasury occurred due to changes in the pay-off system in 1795-1799. This period is characterized by the exemption of tax collectors from the need to take wine exclusively from government warehouses. During the reign of Catherine II, there was an increase in the purchase amounts from the sale of

\footnotetext{
"For the source article, please refer to: Гудакова Л.В., Гребенникова Е.Д. Государственные финансы в период правления Екатерины II // Финансы и кредит. 2020. Т. 26, Вып. 9. С. 2138-2150.

URL: https://doi.org/10.24891/fc.26.9.2138
} 
"drinks", and by 1796 the income increased and amounted to 3450 thousand rubles in 1762.

In 1771 - 6641 thousand rubles, in 1783 - 9419 thousand rubles, in 1786 9564 thousand rubles, and in 1795 - 24.1 million rubles [7].

Throughout history, monetary regalia has been used in Russia to increase budget revenues, despite its medieval character. In 1764, the Empress issued a decree on the coinage of imperials and semi-imperials from gold, from this followed the ratio that existed for a long time in Europe, the prices of gold and silver in the proportion of 15:1. The coin, in accordance with the decree, began to be minted more profitable for the treasury. The income from the operation of the coin regalia is presented in Table 1 [7]. Over time, the income from the minting of gold coins began to decline, but at the same time, the gold coin played an important role in monetary circulation, especially in covering palace and military expenses, since it accounted for a tenth of the total amount of money in circulation.

The analysis shows an increase in the revenue side of the budget due to the collection of duties, but at the same time a decrease in the collection from the coin regalia, since in 1795 the coinage was replaced by the issue of the first paper money. The basic and chain growth rates from duties show a sharp increase in treasury revenues in the period 1790-1795, but at the same time we observe a decrease in the indicators of the basic growth rate from the coin regalia during the reign of Catherine II.

The redistribution of the silver coin was difficult due to the lack of silver in the treasury, so in 1763 a decree was issued that suggested bringing silver coins at a price of 19.5 kopecks to mints.

In addition, the collection of duties from foreign trade had to be partially carried out in a foreign silver coin, while the Instructions to the border customs specifically prohibited the release of "silver in coins" from Russia.

It is necessary to consider separately the collection of duties, which are included in the main part of the state budget income.

Assignats, which were the first paper money, appeared in Russia according to the manifesto of December 29, 1768 [8]. The main reason for the introduction of banknotes was the weight of the copper coin and the difficulty of its circulation. The weight of 1,000 rubles in nickels in a 16-ruble coin was 62.5 poods, and two carts would be required to transport such an amount of money. Another problem should be called the complexity of using copper coins in any financial transactions, for example, to accept 1.00 ruble, twenty thousand nickels had to be recalculated, which led to errors in calculations and there was a need for rechecking. 
For the circulation of state banknotes throughout the country, the need to open an assignation bank to support the country's monetary system and strengthen the assignation ruble was actualized. The prerequisites for the creation of assignation banks in Russia were, according to the nominal decree of May 13, 1754: noble - for nobles in Moscow and St. Petersburg at the Senate and Senate Office - and commercial - for merchants in the St. Petersburg port at the Commercial College, founded during the reign of Elizabeth Petrovna.

As a result of the analysis of the budget policy of Catherine II, we come to the conclusion that the state budget significantly increased revenues due to assignation measures, which led to a significant increase in GDP in the Russian Empire, and served as an impetus for further transformations in the field of monetary policy as one of the components of financial policy.

\section{Monetary policy}

In 1768, on December 29, Catherine II signed the Establishment of the St. Petersburg and Moscow Banks for the exchange of state banknotes. Banks were a single integral system and were under the jurisdiction of the Empress herself. In accordance with the document, all governments and state-owned places must accept banknotes for all state fees for cash without the slightest difficulty. However, Moscow banknotes could be exchanged only in Moscow, and St. Petersburg ones - exclusively in St. Petersburg banks. At the same time, the initial capital was 500 thousand. therefore, it was for this amount that the bank could issue banknotes in denominations of $25,50,75$, and 100 rubles.

But in 1771, in connection with the conversion of 25-ruble banknotes into 75-ruble ones, such were withdrawn from circulation. In May 1771, the noted difficulty in the exchange of banknotes was eliminated. Exchange offices were established in Yaroslavl in 1772, in 1773 - in five more cities, and during the period from 1772 to 1782,23 offices were opened. At the same time, by 1775, banknotes were issued for more than 20 million rubles, they were provided with a coin and there was always an opportunity to exchange them.

The essence of Catherine II's monetary policy is characterized by the emergence of a number of specialized institutions.

Noble, Loan and Auxiliary banks were classified as banking institutions, as they performed the functions of lending, savings, etc., and also during the reign of Catherine II there was a limited number of banks due to the lack of finance to open them. In 1769, Catherine II decided to take a loan from the Netherlands [9]. Russia had not previously turned to foreign banks, and initially the Empress managed with state savings, but due to the military situation and the introduction of paper money, which can be used exclusively within the country, these measures were taken. The bond loan was 7.5 million guilders (physically more than 2.5 tons of gold) at $5 \%$. The pledge for securing payments was 
customs duties from a number of Baltic cities. In 1769, Catherine II adopted a decree on an external loan from the Netherlands in the amount of ten million guilders, as the Russian-Turkish war devastated the treasury. The debt was paid in the amount of 11.5 million guilders in 1779, while the Empress noted: "I care about accuracy in payments in general, and you are not unaware that in my reign we have reached a degree that has never been before; regardless of the credit that is delivered to us by this, we excite amazement of foreigners. I owe the Dutch quite a significant amount, I value very much to maintain our credit so that the next part to be paid is paid on time, at the first opportunity doing it at a time when we are just ending the war and without postponing payments we will surprise even more" [10].

The activities of the government during the reign of Catherine II required the investment of large material resources, so the size of the state budget increased. In 1763, the state budget was 17 million rubles, this figure at the end of the reign of Catherine II, in 1796, increased to 70-80 million rubles.

The emission operations carried out by Catherine II were not the only source of an increase in the revenue side of the budget: tax revenues accounted for most of the increase in the volume of the treasury. Stable tax collection required an improvement in the tax system (Table 2) [7].

The tax policy of Catherine II contributed to the improvement of the economic condition of the country and for this purpose decrees on tax collection were issued. The decree "On the establishment of the provinces of the All-Russian Empire and the transfer of financial management affairs to the State Chambers headed by the Provincial Solicitors of State Affairs" (Pious Autocracy of the Great Empress Catherine the Second institution for the management of the Province of the All-Russian Empire), adopted in 1775, consisted in the fact that a class stratum was formed "trading peasants" who were engaged in trade and crafts.

The "Customs decree" established that persons who are not members of the merchant class can sell products of personal manufacture.

In 1780 Catherine II issued a decree "On the establishment of an Expedition on state revenues, control and audit of accounts, recovery of arrears, shortfalls and deductions", the purpose of which was to control the collection and rational use of state revenues. Not all institutions were included in the expedition, for example, state-owned banks and charitable institutions (shelters, almshouses, etc.) were not its components. The expedition had four independent branches: income, expenses, arrears and control, subordinate to the Prosecutor General.

\section{Customs policy}


The customs policy was based on protectionism [11], that is, it was aimed at supporting domestic producers by restricting imports and imposing high duties on goods that were imported into the country, and mercantilism. Duties were set in certain amounts relative to the category of goods: foreign goods $6-16 \%$; goods with a high value of $60-80 \%$; the price value of duties on goods $12.5-20 \%$, the ideas of free trade that were developed during the reign of Catherine II were implemented in the tariff.

Catherine II based her customs policy on the decree "On the assignment to the actual Privy Councilor Count Minich of the main supervision over all customs duties." Initially, the port and border customs were on state maintenance, later - with the chief director Nikita Shemyakin. In 1764, the Empress ordered the Senate to take customs duties for state maintenance. At the same time, special tariffs were introduced for the Orenburg and Siberian customs, which was under the special jurisdiction of the Siberian Order and had special auctions.

From the Maritime duty regulations that we have analyzed, we learn that Nikita Shemyakin was in charge of customs duties [7], but later the management of this policy was transferred to the hands of the Empress, and we also see the rules of customs throughout Russia. There were certain tariffs that restricted the import of French vodka, wine, salt, taffeta, brocade and other highly valued foreign fabrics. The release of silver and gold was prohibited not only in bullion, but also in coins. At the same time, the highest duty was imposed on Italian silk - 24 rubles, 75 kopecks. In the state chambers, there were posts of border guards and customs detourers, whose duties included streamlining the tax system and the possibility of control for further replenishment of the budget. In 1763, during the reign of Catherine II, a Commission on Commerce was established, its first task was to draw up a new customs tariff.

\section{Financial management system}

The model of financial management during the reign of Catherine II changed the hierarchy of authorities in order to change the management of state finances. Catherine II significantly expanded the financial infrastructure based on the study of European financial institutions. The creation of infrastructure gives impetus, systematization, and streamlining of the financial system (Table 3, Figure 1) [12-14]. In 1775, State Chambers were created (one in each province) as a result of the publication of a Manifesto to solve economic problems such as corruption, the calculation of a large sum of money, etc. (Figure 2).

On October 24, 1780, the first state treasurer was appointed by the Empress, who was guided by the instruction "A collection of laws belonging to the instruction of the county treasurers, how and by what method, until the future publication of the charter of the state chambers, to uniformly send them the position assigned to them" [6]. 
The Empress took a number of measures aimed at improving the financial system, ensuring basic budget revenues: closing monopolies, lowering the price of salt, prohibiting the export of bread abroad, and canceling tax payments.

Catherine II sought to stabilize and facilitate the taxation system, which led to orderly financial management, as a result of these actions, the budgets of cities were strengthened. When analyzing the policy of Catherine II, a parallel should be drawn between representatives of mercantilists who they identified the wealth of the nation and the state with money and treasures. At the same time, they believed that increasing the state's income requires protectionist measures to regulate trade, such measures should include: encouraging exports and curbing imports. During the reign of Catherine II, the financial policy pursued by the Empress strengthened public finances, expanded the financial infrastructure (banking and non-banking institutions appeared), the first paper money was introduced into circulation, and the history of the development of foreign loans began. These processes made it possible to further improve public finances and helped preserve the state's monopoly in the main areas of the financial system.

\section{Table 1}

Budget revenues in 1760-1795

\begin{tabular}{llllll}
\hline Type of income & $\mathbf{1 7 6 0}$ & $\mathbf{1 7 7 0}$ & $\mathbf{1 7 8 0}$ & $\mathbf{1 7 9 0}$ & $\mathbf{1 7 9 5}$ \\
\hline Collection of duties, thousand ruble & 3450 & 6641 & 9419 & 9564 & 241 \\
\hline Average income from coin regalia, thousand ruble & 88.6 & 58.5 & 35.8 & 20.2 & 13.4 \\
\hline Growth rate of duties (basic), percent & - & 1.925 & 2.731 & 2.772 & 69.855 \\
\hline Growth rate from the coin regalia (basic), percent & - & 0.66 & 0.404 & 0.228 & 0.151 \\
\hline The rate of growth of duties (chain), percent & - & 1.925 & 1.418 & 1.015 & 25.198 \\
\hline Growth rate from coin regalia (chain), percent & - & 0.66 & 0.612 & 0.564 & 0.663 \\
\hline
\end{tabular}

Source: [7]

\section{Table 2}

\section{Budget revenues in $\mathbf{1 7 7 5}$}

\begin{tabular}{lll}
\hline Type of duties & $\begin{array}{l}\text { Share of budget revenues, } \\
\text { percentage }\end{array}$ & $\begin{array}{l}\text { Revenue from duties, } \\
\text { thousand ruble }\end{array}$ \\
\hline Indirect taxes & 44 & 30360 \\
\hline Drinking fees (included in the indirect tax) & 22 & 6679.2 \\
\hline Poll tax & 36 & 24840 \\
\hline Customs duty & 11.8 & 8142 \\
\hline Salt payouts & 8 & 5520 \\
\hline Stamp duty & 0.2 & 138 \\
\hline Total & $\mathbf{1 0 0}$ & $\mathbf{6 9 0 0 0}$ \\
\hline
\end{tabular}

Source: [7]

\section{Table 3}

Information on the execution of the State budget of the Russian Empire in 1680-1796

\begin{tabular}{llllll}
\hline Indicator & $\mathbf{1 6 8 0}$ & $\mathbf{1 7 0 1}$ & $\mathbf{1 7 2 4}$ & $\mathbf{1 7 6 3}$ & $\mathbf{1 7 9 6}$ \\
\hline State budget, million ruble & 1.2 & 2.9 & 8.5 & 17.2 & 69 \\
\hline Budget growth rate (chain) & - & 2.42 & 2.93 & 2.02 & 4.01 \\
\hline Budget growth rate (basic) & - & 2.42 & 7.08 & 14.34 & 57.5 \\
\hline GDP, million ruble & - & - & 136.28 & 111.9 & 412.8 \\
\hline
\end{tabular}

Source: [12] 


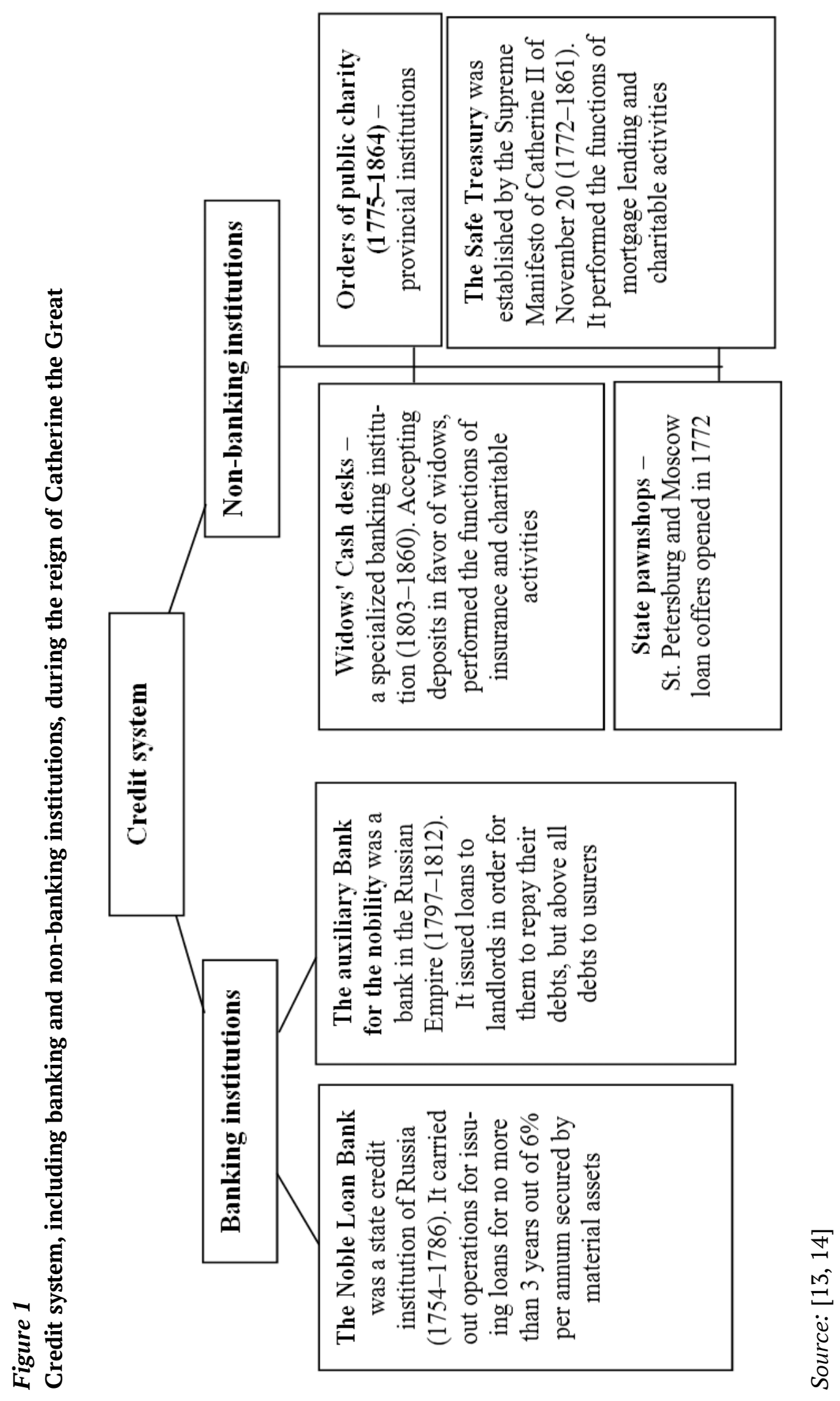


Figure 2

A model of public finance management, and the functions of the Treasury Chamber

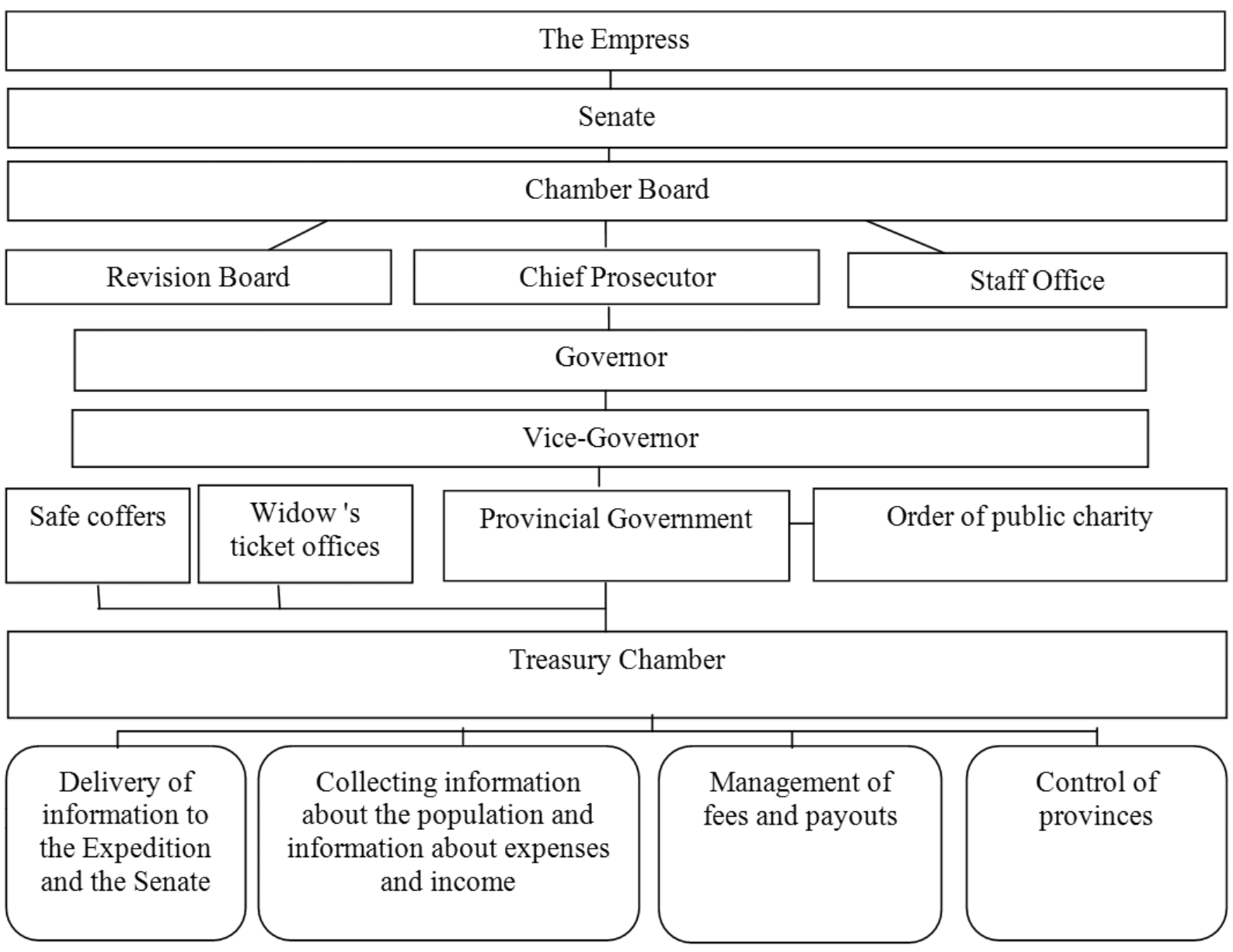

Source: Murav'eva L.A. [The financial policy of Catherine the Great]. Finansy $i$ kredit $=$ Finance and Credit, 2010, vol. 16, iss. 22, pp. 72-80. URL: https://cyberleninka.ru/article/n/finansovaya-politikaekateriny-ii (In Russ.) 


\section{References}

1. Andrianov K.N. [The history of the emergence of money]. Ekonomicheskii zhurnal = Economic Journal, 2003, no. 7, p. 12. URL: https://cyberleninka.ru/article/n/istoriyavozniknoveniya-deneg (In Russ.)

2. Krayushkin K.D. [Economic policy of Catherine the Great]. Molodezhnyi nauchnyi vestnik, 2017, no. 12, pp. 375-377. (In Russ.)

3. Martynov A.G., Chudnov I.A. [Monetary reform of the enlightened age. On the 240th anniversary of paper money circulation in Russia]. EKO =ECO, 2010, no. 6, pp. 163-175. URL: https://cyberleninka.ru/article/n/denezhnaya-reformaprosveschennogo-veka-k-240-letiyu-bumazhno-denezhnogo-obrascheniya-v-rossii (In Russ.)

4. Novikova I.A., Rogachevskaya M.A. [The economic policy of Catherine the Great]. $E K O=E C O, 2010$, no. 8, pp. 158-175.

URL: https://cyberleninka.ru/article/n/ekonomicheskaya-deyatelnost-ekateriny-ii (In Russ.)

5. Saifutdinova G.B., Uvakin A.E., Abubakirova A.R. [Monetary reforms in Russia (historical aspect)]. Uchenye zapiski Tambovskogo otdeleniya RoSMU, 2015, no. 3, pp. 121-126. URL: https://cyberleninka.ru/article/n/denezhnye-reformy-v-rossiiistoricheskiy-aspekt (In Russ.)

6. Andrievskaya V.A. [Monetary reform in Russia during the reign of Catherine the Great]. Ekonomicheskie strategii = Economic Strategies, 1999, vol. 1, no. 1, pp. 60-62. URL: http://www.inesnet.ru/wp-content/mag_archive/1999_01/ES1999-0160-62-Andrievskaya.pdf (In Russ.)

7. Kleandrova V.M., Kut'ina G.A., Novitskaya T.E. et al. Zakonodatel'stvo Ekateriny II. Tom 2 [Legislation of Catherine the Great. Vol. 2]. Moscow, Yuridicheskaya literatura Publ., 2001, 984 p.

8. Gavrikova G.A. [Money, their legal status and role in society]. Pravo i sovremennye gosudarstva $=$ Law and Modern States, 2015, no. 5, pp. 46-50.

URL: https://cyberleninka.ru/article/n/dengi-ih-pravovoy-status-i-rol-v-zhizniobschestva (In Russ.)

9. Baev O.V. [External debt of the Russian Empire in 1775-1787]. Vestnik Kemerovskogo gosudarstvennogo universiteta $=$ Bulletin of Kemerovo State University, 2014, no. 3-2, pp. 106-109.

URL: https:/cyberleninka.ru/article/n/vneshniy-dolg-rossiyskoy-imperii-v-1775-1787gg (In Russ.) 
10. Borisova O.V. [The role of money in the economy]. Nauchnye issledovaniya, 2016, no. 9, pp. 37-39. URL: https://cyberleninka.ru/article/n/rol-deneg-v-ekonomike (In Russ.)

11. Isaev A.P., Shumilov M.M. [The formation of the policy of trade protectionism in Russia (the 17th - beginning of the 18th century)]. Upravlencheskoe konsul'tirovanie = Administrative Consulting, 2012, no. 2, pp. 19-31.

URL: https://cyberleninka.ru/article/n/formirovanie-politiki-torgovogoprotektsionizma-v-rossii-xvii-nachalo-xviii-v (In Russ.)

12. Khanin G.I. [The economy and society of Russia during the reign of Catherine the Great: Progress or stagnation?]. Voprosy statistiki, 2011, no. 4, pp. 64-75. (In Russ.)

13. Bugrov A.V. Kazennye banki v Rossii 1754-1860 gg [Government banks in Russia 1754-1860]. Moscow, Bank of Russia Publ., 2017, 512 p.

14. Gruzitskii Yu. [The Treasury as a mortgage lending institution (1772-1859)]. Банкаўскі веснік, 2010, по. 13/486, pp. 65-68.

URL: http://fox-notes.ru/spravka/PDF_030713_013.pdf (In Russ.)

\section{Conflict-of-interest notification}

We, the authors of this article, bindingly and explicitly declare of the partial and total lack of actual or potential conflict of interest with any other third party whatsoever, which may arise as a result of the publication of this article. This statement relates to the study, data collection and interpretation, writing and preparation of the article, and the decision to submit the manuscript for publication. 